\title{
La imagen del Japón imperial a través de la prensa canaria: los inicios de la segunda guerra sino-japonesa
}

\author{
The Image of Imperial Japan in the Canarian Press: \\ The Beginning of the Second Sino-Japanese War
}

\author{
Ismael Rodríguez Marrero \\ Universidad de Las Palmas de Gran Canaria \\ https:// orcid.org/0000-0002-0517-817X \\ ismael.rodriguezmarrero@ulpgc.es
}

Recibido: 07/09/2020; Revisado: 12/01/2021; Aceptado: 11/03/2021

\begin{abstract}
Resumen
El estallido de la segunda guerra sino-japonesa supuso, junto con la Guerra Civil española, uno de los eventos bélicos preliminares de la Segunda Guerra Mundial. A raíz de ello, tanto España como Japón fueron generando una filia con respecto a Alemania e Italia y también una intensificación de las relaciones hispano-japonesas. Unas relaciones que proyectaron, entre otros elementos, un acercamiento propagandístico del que la prensa canaria no era ajena. Mediante el análisis de las principales cabeceras de Gran Canaria desde julio de 1937 hasta finales de 1938, este trabajo pretende ahondar en la conformación de la imagen del Japón imperial, así como la información de guerra proporcionada durante este conflicto.
\end{abstract}

Palabras clave: Propaganda, Japón, prensa canaria, relaciones hispano-japonesas, segunda guerra sino-japonesa.

\begin{abstract}
The outbreak of the Second Sino-Japanese War was, along with the Spanish Civil War, one of the preliminary military episodes of the Second World War. This led to both Spain and Japan cultivating a relationship with Germany and Italy, as well as an intensification of Spanish-Japanese relations. Amongst other elements, these relations began to display a propagandistic inflection which did not escape the attention of the Canarian press. By analysing the main headlines in Gran Canaria from July 1937 to the end of 1938, this work delves into the construction of Imperial Japan's image, as much as coverage of conflict during the course of the war.
\end{abstract}

Key words: Propaganda, Japan, Canarian Press, Spanish-Japanese Relations, Second Sino-Japanese War. 


\section{INTRODUCCIÓN ${ }^{1}$}

A diferencia de otros periodos históricos, la historia contemporánea se caracteriza, entre otros elementos, por el auge exponencial de fuentes susceptibles de ser compiladas y analizadas por los historiadores. Entre ellas se sitúa la prensa que, a pesar de que su origen se remonta a tiempos más pretéritos del que nos concierne en este trabajo, se erige con especial importancia a la hora de profundizar en aspectos como la opinión pública o en las diversas narrativas políticoideológicas con un afán proselitista, es decir, las intenciones propagandísticas. En efecto, el uso de la prensa como fuente histórica se ha venido dando desde el siglo XIX con una incipiente teorización sobre su uso a inicios del siglo XX después de la Primera Guerra Mundial. Mediante ella, podemos profundizar en la información u opinión pública de la época, así como también realizar un relato histórico sobre las ideologías o las mentalidades y su evolución tal como apunta Jean-Michel Desvors (1999: 69). Una afirmación que cobra sentido si se observa este tipo de fuente como un testigo directo que plasmaba, desde sus diversos prismas, los acontecimientos y procesos que se sucedían. A su vez, la prensa puede contemplarse como una ventana directa hacia el pasado dado que nos muestra a qué tipo de información estaban expuestas las masas del periodo que se quiera abordar. En este sentido y en lo concerniente a la tarea de investigación, la propia labor de la Historia o el Periodismo convergen en diversos puntos como la búsqueda de una veracidad factual respaldada por la aplicación de técnicas rigurosas y con la contrastación de múltiples fuentes.

La utilización de la fuente periodística por parte de los historiadores no difiere mucho de la actitud crítica y las técnicas de investigación aplicadas también al resto de fuentes. Así, la prensa es susceptible de someterse a las diversas técnicas cualitativas y cuantitativas cuya importancia es tal que, como remarca Julio ARÓstegui (2001: 406), «por sí misma constituye, incluso, un campo de estudio historiográfico preciso -historia de la prensa o del periodismo». Una historia que se diferencia, aunque se interrelaciona con ella, de la historia de la propaganda que posee un propio "corpus científico» bien delimitado a la vez que tiene un carácter específico. La propaganda como tal puede definirse como un proceso comunicativo que se subdivide en dos: la información y la persuasión. Este último se erige como objetivo primordial tanto en cuanto se intenta influenciar en la recepción de la información dada. Del mismo modo, el cariz poliédrico de la propaganda, en el que se incluyen los múltiples medios en los que esta se materializa, hace que imbuya diversos procesos de comunicación social. Por tanto, la propaganda es indisoluble del Estado emanando de esta simbiosis con la propaganda estatal o inherente también a la guerra dando lugar a la propaganda de guerra. Así, Alejandro Pizarroso (1999: 145-147) aduce que:

Si la propaganda es un fenómeno comunicativo polimórfico que impregna o al menos puede impregnar prácticamente todos los procesos de comunicación social,

1 Este trabajo ha sido posible gracias a la ayuda a la formación del personal investigador para la realización de tesis doctorales de la ACIISI y el Fondo Social Europeo. 
la Historia de la propaganda no sería otra cosa que la Historia de la Comunicación social ateniendo, eso sí, con particular interés al aspecto persuasivo.

Ciertamente, el elemento persuasivo como característica esencial se muestra con más obviedad en el campo de la propaganda de guerra. Y es que esta no se configura como un medio de entre tantos dirigido al exterior, sino que tiene una especial incidencia en la propia población civil y militar partícipes del conflicto. Ello se demuestra con la preeminencia del rol propagandístico de la Guerra Civil española que se solapa con la segunda guerra sino-japonesa y que, grosso modo, convergen en el desarrollo de ciertas narrativas ideológicas justificadoras de las acciones bélicas. Durante el comienzo de estos conflictos, Canarias, y más concretamente la provincia de Las Palmas que es el lugar que nos atañe, quedaba bajo el dominio del bando sublevado y no tardó en ser testigo de la gestación propagandística característica de los planteamientos franquistas en ámbitos como la imagen favorable del que fue el nuevo Estado en el ámbito internacional. Similitud que comparte con la captación de información externa, en este caso sobre la segunda guerra sino-japonesa, para plasmarla según unos designios ideológicos pautados. Todo ello enmarcado en la intensificación de contactos, sobre todo diplomáticos, entre el imperio del sol naciente y España a partir de 1937. En este sentido, el objetivo primordial de este trabajo es analizar la imagen del Japón imperialista de finales de la década de los treinta, concretamente durante los comienzos de la segunda guerra sino-japonesa (1937-1945), a través de la prensa canaria de la época, cuyos ejemplares comprenden desde julio de1 1937 hasta finales de 1938, desde este enfoque propagandístico-informativo.

\section{METODOLOGÍA Y ESTADO DE LA CUESTIÓN}

Este trabajo tiene como fuentes primarias la compilación y análisis de varios números de la cabecera Falange complementado con ejemplares de Acción y Amanecer: diario de la revolución nacional-sindicalista, desde julio de 1937 hasta diciembre de 1938, recogidos en el archivo digital Jable. ${ }^{2}$ El diario Falange nace de la ambición del Movimiento en «re-españolizar» Canarias el 7 de diciembre de 1936 tras el fallido intento de crear otro diario de corte fascista, Arriba. Por su parte, el diario Acción emergió el 17 de abril de 1935 siendo la voz en la prensa del partido católico Acción Popular. De igual forma, el diario Amanecer tuvo sus inicios en agosto de 1937 y se erigió como portavoz de las consigas de Falange en Tenerife. Su especialidad radicó en la prensa de guerra y en febrero de 1939 se disolvió para dar paso, junto al diario La Prensa, a El Día. Estos fueron los principales exponentes conservadores durante la Guerra Civil dado que las antiguas cabeceras conservadoras, La Provincia, Diario Las Palmas y Hoy fueron censuradas. La idoneidad, por tanto, de estas fuentes radica no solo en la imagen propagandística que pueden ofrecer, sino también en la información de guerra

2 Acceso en línea mediante el siguiente enlace: https://jable.ulpgc.es/ [Ejemplares última vez consultados en diciembre de 2020]. 
que en ellas quedó constatada. Por ende, siguiendo la consideración que pone de manifiesto Pizarroso Quintero (1999: 159) acerca de los diversos elementos que se deben estudiar dentro de la investigación histórica de la propaganda, este trabajo se centrará en el análisis del contenido de los mensajes en su deriva más propagandística, así como la contrastación de los elementos informativos que recogían la evolución de los comienzos de la agresión japonesa a China en 1937. Concretamente el marco cronológico que se atañe es entre julio de 1937 y finales de 1938 como se ha mencionado, siendo esta etapa uno de los momentos de mayor acercamiento entre Japón y España a la vez también del periodo de mayor expansión japonesa en China.

La teorización de la prensa y propaganda en perspectiva histórica, así como la utilización de esta como fuente para la investigación histórica ha sido estudiada por diversos autores como Aróstegui (2001), Dolores (1996), Hernández (2017) y Desvois (1999). Concretamente, la propaganda e información inserta en conflictos bélicos ha sido abordada por PIZARROso (1990; 1999; 2005) y PINEDA (2004) que trazan de manera somera el uso de la prensa como un medio para fines bélicos en los conflictos de la primera mitad del siglo xx. En el caso de España, la conexión entre el aparato propagandístico y de prensa queda bien retratado con los estudios de Sevillano (1998; 1999), Giménez (2015), Pulpillo (2014) o González (2012). Por su parte, uno de los autores que más ha trabajado el ámbito de las relaciones hispano-japonesas, así como la propaganda bélica que se intercambiaba entre estos dos países, es Florentino RodAo García (1993; 1995; 2004; 2013) que se complementa con las investigaciones de Moya (2019a; 2019b) o con las de CENTENO (2019; 2020) siendo este último el que ofrece un análisis de la industria fílmica japonesa durante el periodo de la guerra. Por su parte, PIKE (2008) o HotTA (2007; 2015) ahondan en un marco más general donde se desarrollaron las guerras en España y China mediante el estudio de los contactos internacionales de España con los países del Eje como es el caso de PIKE, o en el detenimiento en los elementos más ideológicos que subyacen a la pura praxis militarista japonesa como pone de relieve HoTTA.

\section{PRENSA Y PROPAGANDA DURANTE LOS INICIOS DEL ESTADO FRANQUISTA}

El estallido de la Guerra Civil española (1936-1939) propició diversos cambios en la futura conformación de la estructura estatal del país ibérico. Así, el primero de ellos en el bando sublevado se manifiesta en el surgimiento de una primigenia organización gubernativa que fue acuñada por Serrano Suñer como «Estado campamental» tras su llegada a Salamanca en febrero de 1937 (citado en PRESTON, 1994: 321-322). Una situación que cambió con la promulgación del Decreto de Unificación en abril de 1937, la reformulación del primer gobierno franquista en Burgos a principios de 1938 y la Ley de Prensa de abril de ese mismo año. Con estos pasos, se hizo evidente la aglutinación de la amalgama de fuerzas sociales que nutrían el joven Estado rebelde (falangistas, monárquicos alfonsinos, carlistas 
y tradicionalistas católicos) y que tuvo su proyección en el campo de la prensa y la propaganda (PIZARROso, 2005: 7).

Concretamente, las ideas que emanaban del preámbulo de la Ley de Prensa de 1938 dejaron claros sus designios ideológicos desde un primer momento. Es por ello por lo que los males del país se resarcirían con «devolver a España su rango de Nación unida, grande y libre, de los daños que una libertad entendida al estilo democrático había ocasionado» (BoE, Ley de Prensa de 22 de abril de 1938, preámbulo: 6938). En efecto, fueron las ideas de un nacionalismo de cariz tradicional junto con una clara posición antiliberal, antimarxista y antidemocrática las que vertebraron los discursos y narrativas en los diversos editoriales de prensa. Del mismo modo, y coincidiendo con la fascistización de los primeros años del Estado franquista de la mano de Falange, las pretensiones de crear una cultura totalitaria a través de la prensa se plasmaron también en esta nueva ley. Así, «siendo la Prensa órgano decisivo en la formación de la cultura popular y, sobre todo, en la creación de la conciencia colectiva, no podía admitirse que el periodismo continuara viviendo al margen del Estado» (BOE, Ley de Prensa de 22 de abril de 1938, preámbulo: 6938). Este proceso obtuvo su inspiración en el modelo propagandístico fascista italiano o de la Alemania nazi. Sin embargo, Francisco Sevillano Calero (1998: 89-90) pone de manifiesto el debate existente entre historiadores sobre la cuestión de la cultura o ideología propia del régimen. Mientras unos abogan por una incapacidad y desidia de los estados fascistas para generar una cultura propia, lo cierto es que las nuevas investigaciones evidencian que los diferentes regímenes se afanaban por la implementación de una auténtica cultura totalitaria en la sociedad en aras de la «nacionalización de las masas».

En el caso de las autoridades franquistas, estas destacaron por su voluntad de conformar una cultura oficial que diseminara la «recatolización» y «respañolización» asentadas en un marco teórico contrarrevolucionario. Esta discrepancia no parece ser marginal ya que son varios los autores que difieren en la carencia o multiplicidad de elementos ideológicos de los grupos franquistas y una difusa unión al respecto (GIMÉnEZ, 2015: 14). En este sentido, uno de los grupos con una innegable elaboración cultural e ideológica clara para su proyección a las masas se observa en Falange tal y como aducen Salvador GiNER y Eduardo SeVIlla (1975: 95). Sin embargo, las intenciones no siempre coinciden con la materialización de los hechos. Y es que la voluntad de Falange de crear de forma autónoma una movilización cultural de corte totalitario se vio truncada por dos factores: la férrea oposición de los actores conservadores y católicos que, a pesar de tener Falange una preeminencia en los resortes e instituciones propagandísticos, lograron difundir en la sociedad unos valores tradicionales de cariz religioso. El segundo factor viene dado por una desmovilización de la población, a causa de la posterior derrota de la guerra y la represión, caracterizada por la resignación y la pasividad con una fuerte influencia de los elementos socializadores de la Iglesia.

Asimismo, la violencia fue un elemento distintivo durante este proceso. Una violencia que también tuvo un rol protagónico en el auge de los movimientos fascistas europeos donde esta, más que ser un medio entre otros para alcanzar la conquista del poder político, se erigió como la impronta identitaria por 
antonomasia de tales ideologías (GentiLe, 2004: 21). Por su parte, la filiación militarista en la organización del aparato de prensa y propaganda franquista se dejó sentir cuando el 14 de enero de 1937 se creó la Delegación del Estado para la Prensa y Propaganda auspiciada por la Secretaría General del Estado con el general Millán Astray como delegado, que ejerció un dominio cuartelero de la organización. Junto a él, el comandante Arias Paz y el comandante Moreno Torres fueron designados también para este puesto tiempo después, aunque finalmente fue Serrano Suñer quien pasó a tomar posesión de este cargo en 1938 así como de la dirección de la Delegación de Prensa y Propaganda de FET y de las JONS (Pizarroso, 2005: 8). Ciertamente, una de las premisas inherentes de la Delegación era la de organizar los servicios informativos, así como sus contenidos con un cariz unificador para luchar contra la propaganda republicana y mostrar una legítima imagen del Estado franquista al exterior. Para ello, la centralización de todos los servicios bajo la nueva organización orquestada por Serrano Suñer se manifestaba como inexorable. La coordinación, el control de los canales informativos y la censura fueron las herramientas aplicadas para la búsqueda de una coherencia y supeditación para con las administraciones y organizaciones regionales o locales de prensa. La nueva organización del aparato propagandístico se caracterizaba por la notoria fuerza que iba cobrando Falange en él. (Pulpillo, 2014: 120-121). El escritor Dionisio Ridruejo fue uno de los principales artífices de esta nueva empresa. Stanley PAYNE (1984: 185) habla de su figura señalando que:

Se dedicó a montar un aparato de propaganda «totalitario» y los elementos más revolucionarios de la Falange ejerciendo casi un control absoluto sobre la información. El joven Dionisio fue calificado de «Goebbels español», comparación a todas luces excesiva, basada únicamente en la escasa estatura física de ambos. Ridruejo era el mejor orador del Partido después de José Antonio, y se esforzó en mantener el «estilo poético» del jefe desaparecido.

Del mismo modo, los mecanismos de violencia se palparon en este ámbito ya desde el decreto del 13 de septiembre de 1936 que permitió la incautación sumaria de los periódicos de izquierda, sobre todo por parte de Falange, y la aplicación de una censura militar. Algunos de los primeros rotativos notorios incautados fueron Arriba España de Pamplona, el periódico nacionalista vasco La Voz de Navarra o la creación del diario gran canario Falange, que es uno de los que nos compete en este trabajo, a causa del cierre forzoso del Diario de Las Palmas. En ellos destacaban «una abigarrada selección de simbología imperial» con un diseño de «extrema religiosidad» $\mathrm{y}$ «su lenguaje simbólico, cortado, imperial y poético, aspiraba a ser la norma literaria del falangismo» (GonZÁlez, 2012: 21). Pero estas no fueron las únicas características intrínsecas de la nueva prensa franquista. A la sazón de los afanes propagandísticos para crear una «cultura de guerra» ligada a una nueva "cultura política», los medios impresos quedarían impregnados de un discurso nacional-patriótico que pivotaba sobre tres elementos que se palpan en los discursos y mensajes empleados: la representación maniquea del enemigo republicano con categorizaciones ligadas al sesgo franquista, «rojos, anti-España, traidores extranjeros, marxistas y masones», la evocación de la figura carismática 
del Caudillo garante del Nuevo Orden y enarbolada con elementos y rituales religiosos, «Alzamiento Nacional o Cruzada», y la colectivización de la memoria mediante el culto a los caídos en la guerra (SEviLLANo, 2014: 235).

La consideración de estos factores no es baladí dado que la propaganda en los medios de comunicación era utilizada por el nuevo Estado como un arma de guerra más. Con ello, «para que los hombres sean capaces de afrontar el horror de la guerra debemos manipular sus emociones, sus sentimientos. Y eso es precisamente la propaganda» como recalca PizArroso (2005: 2). En este sentido, la propaganda de guerra estaría íntimamente ligada al concepto de la guerra psicológica, entendida esta como un tipo concreto de "propaganda orientado hacia el rival». Por ello, la propaganda de guerra se enmarcaría en un fenómeno comunicativo-persuasivo más amplio dirigido tanto al exterior como al interior. Del mismo modo, la piedra angular que vertebra y motiva al aparato propagandístico es el mantenimiento del poder. En efecto, el claro control estatal de los medios de comunicación con afán propagandístico evidencia este rasgo que se ve materializado en la desinformación, el falseamiento o la simple negligencia a la hora de transmitir un determinado mensaje (PINEDA, 2004: 822).

Por su parte, si la organización y los supuestos teóricos del aparato propagandístico franquista estaban bien definidos, no puede decirse lo mismo de su alcance y repercusión social. En este punto entraría en escena uno de los aspectos fundamentales que remarcaba Pizarroso (1999: 159) a la hora de investigar el fenómeno propagandístico en perspectiva histórica: su repercusión y calado en la opinión pública. Una problemática que se agudiza con el alejamiento del periodo histórico que se quiera abordar y se hace casi inevitable «basarnos en conjeturas». Por lo que, de nuevo a la luz de las propias palabras de Pizarroso (1999: 171), «es muy difícil, por no decir imposible en la mayoría de los casos, medir los efectos reales de la propaganda en cada momento histórico» sumado a que la opinión pública «se hace un concepto mucho más difuso, de imposible cuantificación». Esta tesitura se adhiere a la desconfianza existente hacia los medios informativos oficiales franquistas y el acudimiento a los medios de comunicación clandestinos por notorios grupos de la sociedad. Tanto el acceso como sus efectos fueron de carácter reducido, dándose una gran disparidad de los mensajes propagandísticos a raíz del sector poblacional que los recibía, su predisposición y «su propia experiencia cotidiana». Todo ello auspiciado bajo una capacidad informativa atrasada y una mala estructura, especialmente en la prensa (Sevillano, 1998: 166). El ámbito regional no distaba mucho de esta panorámica general. Así, por ejemplo, la población canaria para la década de los treinta y los cuarenta estaba más centrada en su propia supervivencia, dada la nefasta coyuntura económica que estaba experimentando, que en prestar atención a los avatares externos. Incluso, tal indiferencia se aumentaba cuando la prensa empezaba a virar hacia una alineación con el Eje a medida que se desarrollaba la Segunda Guerra Mundial. De la misma forma, la entrada clandestina de prensa ilegal se dejó notar en el archipiélago a la que se añadían las publicaciones antifranquistas de españoles exiliados, entre los que se encontraban autores isleños (DíAz, 2004: 1048-1049). 
Por su parte, el analfabetismo y las bajas tiradas jugaron un rol preeminente en lo concerniente al estudio de la opinión pública y la recepción propagandística. En lo referido a las tiradas, estas no estuvieron bajo un control oficial hasta la creación en 1964 de la Oficina de Justificación de la Difusión (OJD). Anterior a ella, el control y contabilización de las tiradas estaban bajo la actuación de cada empresa periodística que ofrecía datos difusos, mayormente con el número de tiradas incrementadas, motivado por el miedo de perjudicar su papel en el mercado publicitario y dar una cuestionable imagen hacia el lector (SEVILLANO, 1998: 183184). No obstante, la fiabilidad de las fuentes de la época que se encargaban de recopilar los datos relacionados con la opinión pública tiene que ser considerada. En efecto, la creación del Servicio Español de Auscultación de la Opinión Pública, integrada en la Delegación Nacional de Prensa, se encargó de realizar encuestas acordes a la concepción totalitaria de la información. La precisión de la información recabada adolecía de una respuesta que venía condicionada por el compromiso de algunas preguntas, su complejidad, un desconocimiento del tema por parte de los encuestados o la falta de preparación de las propias encuestas. Ello no disminuye el valor de este tipo de fuentes en su calidad de aproximación a una realidad que, claramente, debe ser contrastada (PIZARroso, 1990: 232-233).

Sin embargo, ciertos temas de la propaganda del nuevo Estado franquista habían tenido una aceptable proliferación y acogida. Es el caso de la narrativa que enarbolaba la figura carismática de Franco como garante y precursor del orden y la paz con unos claros valores del régimen, así como el trato y la inserción en la cotidianeidad de la población de asuntos de política exterior y relaciones diplomáticas entre España y diversos países (SEVILLANo, 1999: 158). Por ende, y como aduce Pablo Hernández (2017: 470), todos estos factores impulsan a los investigadores a tratar a la prensa como fuente para identificar y separar la información de la opinión para, a la sazón de estos, analizar el producto periodístico en sí como elemento propio de su contexto. En efecto, la aparición de nuevos medios de comunicación, entre los que se encuentra la prensa, propicia inexorablemente la adherencia, e incluso el desplazamiento tal como apunta Dolores SÁINZ (1996: 139), de las clásicas fuentes de información.

\section{PROPAGANDA Y RELACIONES HISPANO-JAPONESAS}

Mucho antes del estallido de la Guerra Civil española (1936-1939) o de la segunda guerra sino-japonesa (1937-1945), las relaciones e imágenes mutuas que se percibían desde ambos países ya se habían dejado notar. Fue el caso del resultado de la guerra ruso-japonesa (1904-1905) que tuvo repercusiones sobre el semblante nipón que se proyectó hacia España. En efecto, la inesperada y sorprendente victoria japonesa fue percibida desde una perspectiva política favorable dado que España en esos momentos se encasillaba como una potencia marginal dentro del orden internacional. Concretamente, la rápida modernización que experimentó el país del Sol Naciente, especialmente en el ámbito militar, obnubiló a militares y figuras españolas tal como es el caso de Luis Carrero Blanco o Ramón Serrano 
Suñer (RoDAO, 2004: 28). Cabe detenerse en la anecdótica admiración que sentía Millán Astray hacia la ideología adoctrinadora japonesa sobre el código de valores militares que se desarrolló desde finales del siglo XIX y principios del XX. La filia a este código de valores, el Bushidō, alcanzó tal importancia que el propio Millán Astray se inspiró en él para los valores militares que debía seguir la Legión. ${ }^{3}$ El escritor falangista Ernesto Giménez Caballero, uno de los desatacados colaboradores del aparato de prensa y propaganda franquista, recordaba como el fundador de la Legión le espetaba «Mientras no tengas ánimo de samurái, no me sirves» (GIMÉNEZ, 1979: 359).

El desencadenamiento del Incidente de Manchuria en 1931 provocó una tensión en las relaciones hispano-japonesas. La diplomacia de la España republicana se caracterizó durante estos acontecimientos por mostrar una actitud sancionadora en lo relativo a las acciones niponas. Este sentimiento se plasmó, del mismo modo, en la prensa española de la época que recogió una contraposición de opiniones acerca de los movimientos japoneses en China. Este evento, así como la imagen japonesa, quedó en un relativo olvido hasta que se produjo el ataque nipón sobre Shanghái en 1932 y el asesinato del primer ministro Inukai Tsuyosi el mismo año. Estos nuevos sucesos belicistas proyectaron una imagen negativa de Japón en el marco internacional de cariz autoritario y militarista que se agudizó con el abandono de la Sociedad de Naciones por parte del país asiático en 1933. No obstante, los lazos diplomáticos hispano-japoneses se siguieron manteniendo bajo cierta normalidad. En lo referido a imagen propagandística proyectada por los diarios españoles de estos años, ejemplos como el $A B C$ o la revista Blanco y Negro recogieron las acciones japonesas en Manchuria bajo una retórica de complacencia y admiración mientras que remarcaban una clara culpabilidad a China. En este sentido, la imagen forjada en los medios más conservadores años antes de la sublevación se conformaría como el sustrato del imaginario franquista que continuará con la misma línea en el alineamiento ideológico y propagandístico con respecto a Japón (Moya, 2019a: 122-123).

Consecuentemente, desde la década de los 30 del sigloxxlas relaciones hispanojaponesas se caracterizaban por una cierta fragilidad y cuyas orientaciones iban cambiando según los sucesos externos, especialmente con los conflictos bélicos. La España republicana no cortó abruptamente los contactos con Japón al iniciarse el conflicto civil, pero fue solo cuestión de tiempo que estos se vieran encorsetados hasta su finalización con el reconocimiento oficial del Gobierno japonés al Estado de Franco a finales de 1937. Así, por ejemplo, el lingüista José Luis Álvarez Taladriz, encargado de negocios en Tokio por el Gobierno republicano, nunca

3 A finales del siglo xIx, en medio de la vertiginosa modernización que experimentó Japón, comenzó la gestación teórica de la que fue una de las piedras angulares ideológicas dentro del militarismo japonés: el Bushidō (el camino del guerrero). Los valores que emanan de este código fueron discutidos y argumentados por diversos autores a la sazón de la evocación de una imagen mitificada y romántica de la antigua clase samurái. La obra por antonomasia en la que cristaliza esta ideología fue Bushidō. The Soul of Japan escrita por Inazō Nitobe y publicada en 1900. En esta monografía se destaca la proyección de los valores militares hacia el conjunto de la población japonesa. Para una mayor profundización en la construcción del Bushidō y su fuerte unión con el militarismo japonés ver BENESCH (2014); BOLITHO (1984); LÓPEZ-VERA (2016). 
llegó a ocupar su cargo dado el acoso que recibió por parte de agentes franquistas junto a la indiferencia de la policía japonesa a la hora de respaldar su legalidad (MOYA, 2019b: 157).

La intensificación de contactos entre Japón y España a partir de 1937 se vio imbuida por la proliferación de una imagen japonesa idealizada tal y como apunta Florentino RoDAO (1998: 436) que se resume en las siguientes características: la admiración por el progreso, especialmente militar, de Japón como se mencionó anteriormente, la comparación del país del Sol Naciente como una nación diferente y civilizada con respecto a sus vecinos asiáticos a los que se atribuía un semblante de «barbarie» e inferioridad, la similitud de guerras anticomunistas que se solaparon al mismo tiempo en los extremos del continente euroasiático y la inexistencia en España del miedo al «Peligro Amarillo». No obstante, estos contactos nunca se vieron materializados en una ayuda militar tangible de Japón a España como sí había ocurrido con Alemania o Italia durante la Guerra Civil. Estos se centraron más en el mantenimiento de unos lazos diplomáticos, la creación de una imagen propagandística favorable o la utilización de agentes para fines diplomáticos o de mediación en el marco de la guerra. Desde 1937 hasta la finalización de la Segunda Guerra Mundial, las relaciones hispano-japonesas se encauzaron por un valle de altibajos donde las acciones de cada país marcaron los enfriamientos o acercamientos a la sazón de la coyuntura internacional. El estallido de las guerras en España y en China propició, como se ha mencionado, uno de los acercamientos más notorios que cobró su máxima expresión en la firma del Pacto Antikomintern por parte de España en abril de 1939. El estallido del conflicto mundial unos meses después de la firma española de este pacto supuso, además de insuflar bríos renovados en las relaciones hispano-japonesas, un replanteamiento estratégico por parte de los firmantes anticomunistas dado que viraron su enemistad contra Moscú hacia los imperios europeos francés y británico cuya influencia colonial arribaba hasta los territorios asiáticos (RODAO, 2013: 1691).

Uno de los puntos de inflexión en las relaciones hispano-japonesas radicaba en la retórica de la ambición expansionista de ambos países. En efecto, la defensa de la creación de un Nuevo Orden en el marco internacional era un aspecto compartido por las naciones integrantes o con filiación hacia el Eje. Sin embargo, las discrepancias salieron a la luz a la hora de interpretar el imaginario de este Nuevo Orden. Las aspiraciones de Franco por conseguir una mayor preeminencia en el marco internacional bajo la sombra del expansionismo militar norteafricano, la idea de un imperio hispano o el «iberismo» quedaron retratadas en la prensa de la época (GARCía, 2018: 4).

Por su parte, el expansionismo japonés asentó su concepción en la confluencia de diversos elementos que convergieron en la denominada ideología «panasianista». Lejos de conformarse como un sustrato ideológico monolítico e inmutable, lo cierto es que el panasianismo se originó, junto a sus homólogos ideológicos del paneslavismo o panislamismo de finales del siglo XIX, bajo el halo de los derechos civiles del liberalismo internacionalista. Dada las múltiples transformaciones que sufrió, sería equívoco entender el panasianismo en categorizaciones simples. Para 
Eri HоттA (2007: 2) uno de los puntos vertebradores de la lógica panasianista fue la paradójica concepción de este como un «nacionalismo transnacional» que englobaba a todas las sociedades asiáticas dentro de un grupo homogéneo. Este imaginario ideológico evidenció tintes militaristas desde el incidente de Manchuria y la creación del Estado del Manchukuo como la primera nación emergida del panasianismo. A partir de entonces, una de las premisas que cobró más fuerza fue la de la liberación de las sociedades asiáticas del yugo imperialista occidental. Evidentemente, esta liberación tuvo como artífice principal al país nipón que se situó a la cabeza de la denominada «Esfera de Coprosperidad de la Gran Asia Oriental», término usado por vez primera por el ministro de Asuntos Exteriores, Matsuoka Yosuke, en agosto de 1940 (SATŌ, 1994: 6).

Esta nueva proyección no estaba exenta de un discurso racista que bebía de autores de corte supremacista como el filósofo Tanabe Hajime (1885-1962), ${ }^{4}$ de la Escuela de Kioto, que abogaba por una supremacía racial japonesa. Ya en 1932, el Estado de Manchukuo pivotaba sobre la denominada «armonía de las cinco razas» (gozoku kyōwa) en el que se agrupaban chinos, manchúes, mongoles, coreanos y japoneses, siendo estos últimos los que tuvieron que liderar el «Nuevo Orden de Asia Oriental» propagando la civilización y valores japoneses al continente (HоттA, 2007: 110). Precisamente, fue este rasgo racial un elemento preeminente en el desarrollo de la Guerra del Pacífico (1941-1945) que quedó retratado en la propaganda de guerra estadounidense y japonesa en aras de representar al enemigo como un ser infrahumano y legitimar así las acciones bélicas (DOWER, 1986: 73). Esta situación condicionó, entre otros factores, la alianza entre España y Japón que Florentino RODAO (2013: 1708) calificaba: «con expectativas brillantes, pero también con unas contradicciones importantes que socavaban el futuro a más largo plazo».

Por otra parte, y en lo concerniente a la materialización de estos lazos por las vías más diplomáticas o de espionaje, en septiembre de 1939 se instaló una red de espionaje en la embajada española en Londres financiada por Alemania y controlada en parte por el embajador japonés en Madrid, Suma Yakichiro. El objetivo primordial de esta red, llamada Tō (traducido literalmente como «puerta» o también «este» como punto cardinal), era conocer los movimientos de los convoyes marítimos aliados. Este espionaje cobró una nueva dimensión cuando Japón atacó Pearl Harbor en diciembre de 1941 dado que España se erigió como uno de los mejores candidatos para jugar el rol de mediador en las relaciones entre japoneses y estadounidenses. Con el abandono de la representación diplomática japonesa en Washington, España recibió 500.000 dólares para el mantenimiento y extensión de las operaciones Tō en el país norteamericano (PIKE, 2008: 71).

Los intereses japoneses en América venían marcados no solo por las misiones de espionaje, sino también por la gran cantidad de colonias niponas que estaban establecidas por el continente, especialmente en Perú, Brasil o Estados

4 Tanabe Hajime fue integrante, junto con Nishida Kitarō y Nishitani Keiji, de la Escuela de Kioto. Influenciado por el idealismo alemán al igual que el resto de los filósofos de esta escuela, Tanabe reflejó sus ideas supremacistas en su obra La lógica de la especie como dialéctica que bebe del sistema dialéctico hegeliano. Para profundizar ver Dilworth y TAIRA (1969). 
Unidos. Fue en la nación angloamericana donde España desempeñó un papel más notorio. La inclinación por el país ibérico para esta tarea vino condicionada por dos factores: una mejor capacidad técnica que se traducía en una amplia red diplomática y la alineación política marcada por la imagen propagandística de una amistad anticomunista. Fue esta última característica la más destacable por la cual giraban las relaciones hispano-japonesas y que se nutrían de las victorias que iba cosechando el Eje en los inicios de la guerra. Sin embargo, esta dinámica fue cambiando a medida que los Aliados comenzaron a contrarrestar el expansionismo nipón a partir de 1942 con la batalla de Midway como punto de inflexión. El cambio de tornas en lo militar tuvo sus repercusiones claras en las relaciones diplomáticas y en la imagen propagandística. Otros de los factores que agudizaron el declive de las relaciones fue la política de no agresión por parte del Gobierno de Tokio a la URSS cuando ya Alemania había comenzado a avanzar contra esta en julio de 1941. Incluso ante los ojos de los grupos fascistas más projaponeses esto resultó verdaderamente sorprendente a la vez que decepcionante.

A todo ello se le sumó el viraje español de la no beligerancia hacia nuevamente la neutralidad que fue pilotado bajo el nombramiento de Francisco Gómez-Jordana Sousa como nuevo ministro de Asuntos Exteriores en agosto de 1942. La prioridad por la neutralidad fue en detrimento de la actitud de acercamiento a Japón manifestado en la etapa de Serrano Suñer. Con ello, la actividad intermediadora en EE. UU se vio comprometida doblemente: por una parte, el Gobierno nipón se quejaba cada vez más de las ineficaces labores de supervisión y recopilación de información sobre las colonias niponas recluidas en los Centros de Realojamiento de Guerra y, por otra parte, el Gobierno español protestó ante el embajador Suma por el tratamiento de la colonia hispana en Filipinas. Por tanto, no es de extrañar que, dadas las condiciones, las relaciones hispano-japonesas fueran entrando en debacle. En este sentido, y a la sazón de que la guerra se decantaba hacia el bando aliado, cabe destacar el oportunismo del gobierno de Franco en aprovechar cualquier coyuntura para su supervivencia, máxime ello supusiera cortar los lazos de ayuda humanitaria que desempeñaban los diplomáticos y agentes españoles motivado, en parte, por la mala imagen propagandística que se difundía en la nación angloamericana (RoDAO, 1995: 187-188).

No obstante, durante y después de la Guerra Civil, la filiación que se tenía con Japón se veía multiplicada cuando se producían acercamientos con Italia y Alemania. Así, la prensa de 1940 cobra un evidente cariz beligerante dentro del marco de la no beligerancia española. La germanofilia y la mayor afluencia de noticias provenientes de agencias extranjeras del Eje se produjeron con la entrada de Italia en la guerra. Las agencias DNB y Transocean por parte de Alemania y la Stefani por parte de Italia eran las principales suministradoras de información en estos países. De hecho, los únicos corresponsables de prensa que poseía el Estado franquista para 1939 se hallaban en Roma y Berlín constatándose así la precariedad de medios de los que disponía el aparato de prensa y propaganda (GARCíA, 2018: 13). El Gabinete Diplomático de la Junta de Defensa Nacional, transformado en el Ministerio de Asuntos Exteriores en 1938, fue, desde el primer momento, el principal artífice en regular las oficinas de prensa franquistas en el exterior y en 
buscar apoyos ideológicos bajo las directrices de Franco (Moreno, 2008: 51).

Por su parte, los agregados de prensa en el extranjero informaban a la Sección de Prensa Extranjera del Ministerio de Exteriores sobre las dinámicas de prensa en el país que se situaban mediante recortes de prensa con especial mención a aquella información de cariz político y que aludiera a España. Del mismo modo, estos debían de tratar de influir en la prensa del país en el que se encontraran mediante la ayuda del Negociado de Agencias. En lo referido a los corresponsales extranjeros que llegaban a España, era la sección de Corresponsales, una de las secciones que conformaba la Delegación Nacional de Prensa de la Vicesecretaría de Educación Popular, la que se encargaba de controlar y documentar a los agregados de prensa extranjeros. Para el caso de Japón, las noticias provenientes de este país venían de la mano de la Agencia Dōmei con Kojima Ryoichi como director de esta y agregado en España (Moreno, 2008: 204).

Sin embargo, la prensa no fue el único medio al servicio de la guerra por el que fluía la propaganda totalitaria. La radio cobró un desarrollo e importancia sin precedentes en España, tal y como aduce Pizarroso (2005: 1), durante la Guerra Civil a pesar de estar por detrás de sus homólogos europeos. En efecto, la ventaja e innovación que suponía el hecho de que los mensajes se retransmitieran instantáneamente a los diversos frentes de batalla fue un aspecto crucial. Esta cualidad fue aprovechada por el bando sublevado para sus fines propagandísticos a la hora de retransmitir el seguimiento de la guerra tanto al interior como al exterior. Así, la radio jugó un rol protagónico en los inicios del levantamiento militar que fue retrasmitido por Radio Las Palmas, Radio Club Tenerife, Radio Tetuán o Radio Ceuta a las que se sumarían otras radios regionales del país a medida que avanzaba la contienda (PiZARroso, 2005: 10).

Pero, si hubo un medio prolífico y notorio a la hora de transmitir información este fue el cine. La captación y representación de la realidad mediante imágenes con una fuerte carga simbólica fue uno de los elementos esenciales en este potente medio de comunicación. Para la década de los treinta del siglo xx el noticiario documental se erigió como formato preferido en la producción cinematográfica dedicada al ámbito de la guerra. Precisamente, fue en el país nipón donde la elaboración de estos noticiarios cobró una importancia elevada y fueron confeccionados por los principales periódicos nacionales como Asahi Sekai Nyusu (Noticias del Mundo Asahi), Daimai Tōnichi Nyusu (Mainichi Osaka-Tokyo Noticias Diarias), Yomiuri Nyusu (Noticias Yomiuri) o la propia Agencia Dōmei que lanzó su noticiario Dōmei Nyusu (Noticias Dōmei) en 1936. ${ }^{5}$ Sea como fuere, tanto en los medios de comunicación escritos, radiofónicos y cinematográficos las narrativas propagandísticas quedarían supeditadas al desarrollo de la guerra y a la política exterior española con respecto a Japón que, como se mencionó anteriormente, dieron un giro irreversible a partir de 1942. Así, en palabras de Florentino RoDAO (2013: 6849):

Este segundo periodo de Jordana, en definitiva, ofrece el ejemplo más claro de

5 Para una mayor profundización en el desarrollo de la industria fílmica japonesa, especialmente de los noticiarios de guerra, y su llegada y cambio en el ámbito español ver CENTENO MARTín (2020). 
dualidad en la relación entre ambos países, porque frente a esa imagen amistosa ante el exterior, cada uno estaba dispuesto a traicionar al otro, si así convenía a sus intereses. La relación era esencialmente inestable porque comenzaba a considerarse que el otro no sólo era inútil para la consecución de sus objetivos, sino que incluso los obstaculizaba.

\section{LOS INICIOS DE LA SEGUNDA GUERRA SINO-JAPONESA A TRAVÉS DE LA PRENSA CANARIA: HERMANDAD ANTICOMUNISTA E INFORMACIÓN DE GUERRA}

En este apartado conviene exponer, previa y someramente, el desarrollo general de la segunda guerra sino-japonesa para tener un marco de referencia a la hora de profundizar en las siguientes cuestiones. Este conflicto puede dividirse en dos claros periodos. El primero de ellos, que es el que atañe a este trabajo, coincide con el momento de mayor expansión japonesa en China. Dio comienzo con el incidente del puente de Marco Polo en julio de 1937 y prosiguió hasta finales de 1938 cuando las conquistas niponas se estabilizaron. ${ }^{6}$ Respecto al segundo, este quedó inserto entre 1939 hasta 1945, cuando las fuerzas imperiales quedaron inmersas en un proceso de estancamiento marcado por avances y retrocesos constantes. Además de las principales ciudades y puertos de la costa oriental china, las conexiones ferroviarias de Tianjin-Pukou y Pekín-Wuhan eran también otros objetivos militares importantes. Durante la segunda mitad de 1937 fueron varios los enclaves y puntos que cayeron en manos japonesas como Shanghái, Nankín, la conexión Tianjin-Pukou, la provincia de Chahar, Shanxi y la zona baja de la región del Yangtzé. Con estas conquistas los japoneses albergaron la esperanza de realizar una campaña corta y, con ello, hacer claudicar a Chiang Kaishek lo antes posible. Lo cierto es que la realidad se truncó contra las expectativas de los mandatarios nipones y pronto se encontraron en la tesitura de hacer frente a vastas extensiones territoriales en el interior de China donde las tácticas de flanqueo y cercamiento resultaron inadecuadas para combatir a las tropas del Kuomintang. Pero si los japoneses se habían quedado sin ideas para forzar la rendición china, el Generalísimo tampoco sabía o era incapaz de idear nuevas formas para repeler la invasión. Sin embargo, con la toma de Wuhan y Cantón por parte de las fuerzas imperiales en la segunda mitad de 1938, y estableciendo con ello el límite de la expansión nipona, el repliegue chino hacia la provincia de Sichuan y el restablecimiento de la capital en Chongqing trajo consigo un nuevo replanteamiento estratégico para enfrentar a los invasores (DREA; VAN DE VEN, 2011: 30-35).

En efecto, la nueva fase del estancamiento japonés en lo referido a sus conquistas estuvo marcado por el acoso guerrillero de las tropas chinas en vez

6 Para la historiografía japonesa existe un debate en torno al concepto de la «Guerra del Pacífico» dado que este resalta el punto de partida del conflicto en Asia con el ataque japonés a Pearl Harbor en 1941, solapándose de este modo con la Segunda Guerra Mundial. El reconocimiento claro de la guerra en este escenario para los autores nipones comenzó con el incidente del puente de Marco Polo e, incluso, algunos sostienen que con la ocupación de Manchuria seis años antes. Véase HоттA (2007). 
de una confrontación directa. Este hostigamiento fue combatido por una nueva estrategia antiguerrillera promovida por el que fue el nuevo comandante del Ejército Expedicionario al norte de China en 1941, el general Okamura Yasuji. Con él se llevó a cabo la denominada política de «Los tres todos» que consistía en «matarlos a todos, quemarlo todo y saquearlo todo», o, en otras palabras, una política de contrainsurgencia basada en el terror. La inserción de Estados Unidos en el conflicto tras el ataque de Pearl Harbor en diciembre de 1941 condicionó las acciones japonesas en el teatro chino. Así, los preparativos nipones para la captura de Chongqing en septiembre de 1942 tuvieron que ser pospuestos ante el desembarco norteamericano en Guadalcanal. Del mismo modo, desde los inicios de la campaña en China los japoneses adolecían de serios problemas en torno a los recursos logísticos, de abastecimiento y un agotamiento extendido de las tropas. Algunos territorios fueron perdidos como el norte de Birmania, pero en general las fuerzas imperiales seguían manteniendo su presencia en los territorios donde se habían expandido inicialmente. En este sentido, la última gran ofensiva en China se llevó a cabo en abril de 1944 bajo la operación Ichigō que consistió en la destrucción de las bases aéreas estadounidense en China. Finalmente, el desalojo de los japoneses no llegaría hasta su definitiva derrota en agosto de 1945 (Drea; VAn De Ven, 2011: 39-45).

Retornando al ámbito de los medios de comunicación escritos, al igual que el resto de los periódicos regionales, la prensa canaria se inspiró en la proyección doctrinal editorial del que fue el verdadero vertebrador periodístico del Movimiento: el diario Arriba, siendo este el periódico español con mayor filiación hacia el Eje y, por ende, más pro-japonés (Sevillano, 1998: 179). Con ello, una de las más claras características de la prensa canaria a la hora de referenciar al país del Sol Naciente era su alineación propagandística. La gran admiración hacia la nación japonesa radicaba en los rasgos de su auge militar moderno, así como de su afán anticomunista:

El Japón comprendió lo que tenía que hacer. Empezó su Era nueva señalada por una transformación a lo occidental, y sabiendo que para ser respetados es preciso ser fuertes, se dedicaron, sobre todo, a aumentar el poder militar del país (...) Tenía muy cerca el ejemplo de China (...) Japón no quiso correr la misma suerte. Sus estudiantes frecuentaron las universidades europeas, sus técnicos conocieron nuestros secretos, y aquel pueblo unido y vibrante de patriotismo ideal, se convirtió en una gran potencia. Asombró al mundo en la guerra chinojaponesa, venció al Oso ruso en el Puerto Arthur y le hizo firmar una paz ventajosa (...) Seamos fuertes y empleemos, como Japón, la fuerza al servicio del bien. ${ }^{7}$

La mayoría de las imágenes favorables que se ofrece por parte de Japón en su vertiente más propagandística se producen a finales de 1937 coincidiendo con varios sucesos como la rápida expansión japonesa hacia el sur de China o el reconocimiento oficial de España por parte del país nipón. Precisamente, fue este reconocimiento uno de los eventos más destacados y adornados de una

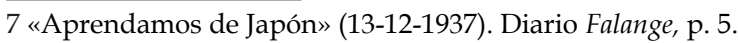


brillante estrategia en el ámbito internacional en la prensa canaria. En efecto, el reconocimiento oficial tenía como consigna retórica «la lucha a fondo, con calidades de operación quirúrgica, para extirpar al comunismo». ${ }^{8}$ Dado que «en Asia como en España se vive la hora de la verdad $»^{9}$ parecía inexorable que de las similitudes de guerras en ambos continentes se forjara una especie de hermandad anticomunista que cristalizó en «la cadena que los pueblos forman alrededor del mundo para salvarlo de la caída en el caos soviético». ${ }^{10}$ A este gran afán anticomunista se le suma «el más formidable triunfo de nuestra diplomacia» ${ }^{11}$ que consigue, además de sus victorias en ámbito militar, «Una victoria en lo internacional». ${ }^{12}$

Esta brillantez en las labores de la política exterior se reflejaba también en los anteriores reconocimientos por parte de otras naciones: «también Polonia y Yugoeslavia se disponen a mantener relaciones con la España Nacional» o «el gobierno húngaro considera a la España Nacional como la verdadera España». ${ }^{13}$ La enfatización de estas promulgaciones venía siguiendo la estela de la adhesión italiana al Pacto Antikomintern en noviembre de 1937. De este pacto se resaltaba que «no va contra ninguna potencia, sino que asume un sentido de defensa cultural». ${ }^{14}$ Los detalles del acuerdo se reducen a su razón de ser en la lucha contra el comunismo siendo más abundantes los elogios de Von Ribbentrop, el conde Ciano o el embajador Hotta sobre el pacto. Por su parte, la posible adhesión española al acuerdo se dejó entrever por la prensa aduciendo que «la España nacionalista y el Manchukuo firmarán su adhesión al Pacto Antikomintern el día veinticinco del actual mes de noviembre». ${ }^{15}$ Una información que el diario Falange recogió de los periódicos japoneses «Hasani Shimbun» (refiriéndose al diario Asahi Shimbun) y el «Nichinichi Shimbun» (correctamente el Tōkyō Nichi Nichi Shinbun) a través de la agencia Dōmei, creada justo en 1936 a la sazón de las intenciones gubernamentales centralizadoras de la información. Es común observar en la prensa insular diversos errores de traducción, sobre todo en las noticias internacionales que aludían a Japón o a China. El Tōkyō Nichi Nichi Shinbun era el diario más afín a las acciones del Eje.

Por su parte, la prensa japonesa recogió los acontecimientos de la Guerra Civil española con cierta negligencia en lo concerniente a la veracidad de la información $\mathrm{y}$, a menudo, a través de noticias de otros periódicos, especialmente de origen norteamericano. Ello provocó que en diversos diarios nipones se mostraran contradicciones e, incluso, una visión crítica respecto a la figura de Franco. En España, fue Sakai Yoneo uno de los principales corresponsales del periódico Asahi Shimbun el que recogió las principales noticias del país ibérico

8 «La cadena de los pueblos» (06-12-1937). Diario Falange, p.1.

9 Íd.

10 Íbid.

11 «Japón y la España Nacional» (22-11-1937). Diario Falange, p. 1.

12 Íd.

13 «España en el concierto de las Naciones» (20-11-1937). Diario Falange, p.1.

14 «El pacto germano-nipón contra el comunismo quedó ayer firmado por Italia» (07-11-1937). Diario Falange, p.1.

15 «España en el concierto de las Naciones» (20-11-1937). Diario Falange, p.1. 
(RoDAO, 1993: 139).

Sin embargo, lo que la prensa canaria no plasmó sobre estas victorias diplomáticas son las dificultades que encontró el Gobierno de Franco a la hora de ser reconocido por Japón. En efecto, el acercamiento oficial por parte de ambas naciones no estuvo exento de enfriamientos y enfrentamientos internos. Así, uno de los factores favorables para el reconocimiento de la España nacional fue la figura de Konoe Fumimaro, a mediados de 1937 primer ministro, que era más proclive al reconocimiento franquista junto con el apoyo de la facción del Ejército que tenía peso en el Gobierno nipón. En España, el reconocimiento por parte de Japón era visto con esperanzas de que le siguieran otras naciones como así se evidenció con orgullo en la prensa: «Ayer, reconocimiento por el Japón. Hoy, reconocimiento por el Manchukuo de nuestro Gobierno Nacional. Mañana, Holanda, que se apresta al reconocimiento», ${ }^{16}$ acompañada la noticia principalmente por felicitaciones y halagos sobre figuras como el ministro Hirota, el agregado de Negocios de la Legación española en Tokio Francisco José del Castillo o el propio Franco y el reconocimiento de la mediación italiana. A su vez, esta información se vería concatenada en los siguientes días con otras también en lo referente a las relaciones internacionales, como es el caso de la prohibición de la entrada en Japón de españoles con pasaporte republicano con el usual lenguaje propagandístico: «Mientras la España nacional se abre paso ante las demás naciones, se cierran las puertas a los rojos (...) los pasaportes visados por las autoridades rojas serán considerados nulos y los que los lleven no podrán pisar territorio japonés». ${ }^{17}$

Pero, fue del Castillo el que tuvo que mediar en las negociaciones para el reconocimiento de la España del Caudillo en solitario. Un reconocimiento que conoció detractores en el Gobierno japonés con figuras como el ministro de Asuntos Exteriores Hirota Kōki o los condes de Matsudaira y de Makino, ambos integrantes del Consejo Imperial. A mediados de septiembre de1937las intenciones del Castillo sufrieron una decepción dada la negativa inicial de Alemania e Italia para mediar entre la Legación española y el Gaimushō (Ministerio de Asuntos Exteriores). Una negación que estuvo inserta en un marco internacional delicado para Japón puesto que la guerra en China había ocasionado ciertos incidentes con el Gobierno británico, concretamente sobre el ametrallamiento del embajador británico en China por parte de la aviación japonesa que quedó saldado con una indemnización. Ello quedó retratado en la prensa: «Inglaterra acepta las excusas del Japón, quedando así zanjado el grave incidente». ${ }^{18}$ En la noticia se recoge también la intención japonesa respecto a los bombardeos que se sucedieron sobre Nankín en septiembre aduciendo que «Los japoneses no atacan a la población civil, ni se propone perjudicar los derechos de los súbditos a las terceras potencias», ${ }^{19}$ algo que no llegó a cumplirse.

Para finales de octubre, esta dinámica internacional pareció cambiar, así como

16 «Una victoria internacional por día» (02-12-1937). Diario Falange, p.1.

17 «A las tres de la tarde de ayer los japoneses entraron en Nankín» (11-12-1937). Diario Falange, p. 8. 18 «Inglaterra acepta las excusas del Japón» (23-09-1937). Diario Falange, p. 4.

19 Íd. 
los acontecimientos en China, a favor del reconocimiento franquista. Uno de los factores que propulsó este viraje fue la adhesión italiana al Pacto Antikomintern. Por su parte, Japón puso como condición que España reconociera al mismo tiempo al Estado del Manchukuo en aras de que otras naciones siguieran su ejemplo. Del mismo modo, la culminación de estos acercamientos iniciales se produjo con la integración española en el Pacto Antikomintern que en un primer momento el gobierno de Franco quería hacer secreta (RoDAO, 1993: 171-176). Quizá por ello no se ha encontrado constatación del reconocimiento del Manchukuo o de la unión al pacto por parte de España en la prensa canaria.

Unas semanas antes del conflicto en China, las pretensiones japonesas por construir un Nuevo Orden en Asia, con claros tintes panasianistas anteriormente retratadas, quedaron plasmadas en la prensa con el titular «Oriente exige su personalidad». ${ }^{20}$ En efecto, «El ministro-presidente japones Hiranuana [correctamente Hiranuma] ha exhortado al pueblo chino a liberarse de los influjos de las potencias occidentales disponiéndose a construir un nuevo orden en Asia Oriental de acuerdo con el Japón y el Manchukuo»». ${ }^{21}$ Asimismo, otro ejemplar recoge la reunión de organizaciones de juventudes asiáticas provenientes de la India, Siam, el Manchukuo, el norte de China y Mongolia para la adherencia del partido Antikomintern, aunque no se especifica el lugar y más detalles de los participantes o sus organizaciones. A su vez, esta noticia es seguida por otra que sostiene que «el Gobierno japonés no tolerará la intervención de extranjeros». ${ }^{22} \mathrm{Es}$ en este tipo de información donde la contradicción ideológica entre el Gobierno franquista y el japonés se pasa por alto no solo por la imagen estereotipada favorable sobre Japón, sino también por la propia dinámica interna de España donde las preocupaciones estaban más centradas en ganar la guerra que en tomarse la expansión colonial como una prioridad.

El estallido de la segunda guerra sino-japonesa fue recogido por la prensa insular bajo una retórica de tensiones diplomáticas en la que subyace como principal provocador el Gobierno chino. Por el contrario, «Las intenciones del Japón son las de actitud conciliadora, estando dispuesto a entablar negociaciones a base de la retirada de tropas». ${ }^{23}$ Del mismo modo, el incidente del puente de Marco Polo del 7 de julio de 1937, como evento iniciador del enfrentamiento, está ausente en las noticias internacionales de la prensa. La única mención que se tiene de este suceso se recoge en el diario Amanecer en noviembre de 1938 y se plasma bajo una clara retorica propagandística donde la culpabilidad del conflicto reside en China que, tras haberse dejado embaucar e influenciar por las acciones comunistas y judías, había forzado a Japón a entrar en la senda belicista. ${ }^{24}$ Los siguientes días al incidente, y a raíz de los enfrentamientos continuos, la actitud agresora japonesa, pero siempre justificada, se hizo más evidente: «El Japón y el

20 «Oriente exige su personalidad»(03-06-1937). Diario Falange, p.6.

21 Íd.

22 «Japón no tolera intervenciones en el conflicto chino-nipón» (04-11-1937). Diario Falange, p. 4.

23 «El grave conflicto chino-japonés sigue pendiente de solución» (22-07-1937). Diario Acción, p. 8.

24 «Orígenes de la guerra chino-japonesa. Intrigas del judaísmo y del bolchevismo contra el Japón» (23-11-1938). Diario Amanecer, p. 2. 
Mandshukuo [Manchukuo] marcharán unidos contra el comunismo en el deseo de hacer un lejano Oriente lleno de grandeza». ${ }^{25}$ Shanghái fue el primer punto estratégico en el expansionismo nipón. La fuerza naval japonesa en el delta del río Huangpu de esta ciudad estaba formada por la $3^{\text {a }}$ flota compuesta de la décima y undécima divisiones de barcos de combate, de los cuales la mayoría eran cañoneros fluviales seguidos por destructores, corbetas y cruceros protegidos, y reforzada con tres portaviones (LAI, 2017: 21). De la misma noticia se recoge que esta guarnición fue reforzada con «dos destructores». ${ }^{26}$ Con ello, «ante las constantes provocaciones de China, el Japón sigue teniendo fondeados barcos en las aguas de Shanghai». ${ }^{27}$

Una de las maniobras más ambiciosas a mediados de agosto por parte de Chiang Kai-shek era la de asestar un golpe sorpresa sobre la flota japonesa anclada en el puerto del citado río, con las miras fijadas en el crucero protegido japonés Izumo como objetivo principal. Ello no queda evidenciado en la prensa a pesar de las fatídicas consecuencias que tuvo debido a fallos por parte de la aviación china que bombardeó lugares concurridos de la ciudad como el camino de Nankín, el hotel Cathay o la Avenida Eduardo VII (MitTER, 2013: 112). Por otra parte, durante los combates de Shanghái para mediados de octubre se recogió la cifra de combatientes chinos «de un millón de soldados instruidos militarmente (...) En caso de ser necesaria una movilización en Kwangsi podrían reclutarse otros tres millones de hombres». ${ }^{28}$ Una cifra exagerada dado que para principios de noviembre el total de movilizados era de un máximo de medio millón de soldados de los que derivaron 187.000 bajas entre muertos y heridos (MitTeR, 2013: 121). De igual forma, el avance japonés se plasmó de una forma confiada y sobrada de fuerza tanto en el frente del norte de China como en Shanghái:

En el Norte las tropas japonesas después de una lenta y sabia preparación caen como torrentes sobre la región al Oeste de la antigua capital, encontrando tan sólo la resistencia de tropas mal pertrechadas y mal entrenadas para resistir al armamento modernísimo que los japoneses tienen en gran cantidad. No nos extrañaría que después de consolidadas las regiones ocupadas en el Norte por los japoneses, se parase [pasase] a la acción de las tropas desembarcadas cerca de Shanghai. ${ }^{29}$

En efecto, el posterior ataque anfibio del $10^{\circ}$ Ejército japonés en la bahía de Hangzhou el 5 de noviembre al sur de Shanghái contribuyó de manera decisiva a la inminente caída de la ciudad. Sin embargo, y a pesar del impecable y arrollador avance nipón expuesto en la prensa, para finales de octubre las bajas japonesas ascendieron a un total de 42.202 entre heridos y muertos (MITTER, 2013: 146). Para finales de noviembre y principios de diciembre la caída de Shanghái fue definitiva y, con ello, la acelerada llegada y conquista de Nankín en las dos primeras semanas de este último mismo mes. Durante este lapso el Grupo de

25 «El Japón no cede un paso» (10-07-1937). Diario Falange, p.8.

26 Íd.

27 «Los incidentes entre China y Japón» (15-07-1937). Diario Acción, p.1.

28 «Los japoneses concentran sus tropas para atacar Shanghái» Diario Falange, p.4.

29 «El plan japonés prevé la desintegración de China por el Norte» (02-10-1937). Diario Acción, p.4. 
Voluntarios Soviéticos, compuesto por pilotos de los cazas Polikarpov I-16, fue enviado en ayuda a China como consecuencia del pacto de no agresión firmado entre la URSS y el Gobierno republicano chino (LAI, 2017: 43). No hay constancias de la aparición de esta fuerza en la prensa canaria salvo su breve referencia en el diario Amanecer en la segunda quincena de diciembre que fue cuando los pilotos soviéticos intensificaron su presencia en las cercanías de Nankín al interceptar a la aviación nipona: «Pilotos yanquis y rusos al servicio de los chinos (...) cincuenta aparatos soviéticos con tripulaciones moscovitas han llegado a china tomando parte activa en los combates aéreos en la zona de guerra». ${ }^{30} \mathrm{La}$ única información acerca de los combates aéreos que se ofrece por parte de Falange, principal difusor de la propaganda franquista en Gran Canaria, para este periodo es muy vaga donde apunta que entre las zonas de Shanghái y Nankín se produjo «una gran actividad y los aviones japoneses volaron repetidas veces sobre el frente de combate». ${ }^{31}$

Lo que sí se recogió fue el acercamiento del ejército japonés a Nankín. Así, en los días anteriores a la capitulación definitiva de la capital china Japón mostró una imagen conciliadora con esperanzas de arribar a un cese del conflicto siempre que «el gobierno chino se decida a abandonar su actitud antijaponesa colaborando abierta y lealmente con Japón». ${ }^{32}$ Una actitud contraria a las ya definidas maniobras de las tropas imperiales que trazaron un plan de ataque simultaneo por varios puntos entre los que se encontraban el ataque naval por el río Yangtzé: «En el Yangtse han logrado los barcos de guerra romper la barrera del río avanzando hacia Nankin»». ${ }^{33}$ A los dos días siguientes ya la prensa proclamaba la ocupación efectiva, a pesar de que esta se produjo el 13 del mismo mes, bajo el titular «Japón ha plantado sus banderas en Nankin». ${ }^{34}$ Aunque no se expone el grado de avance dentro de la ciudad, sí se detalla el avance del desarrollo de las maniobras en el Yangtzé. Del mismo modo, en el ejemplar de Acción de ese mismo día se ensalza las acciones de la «gloriosa Marina japonesa ${ }^{35}$ en la captura de un barco chino o en la entrada de la ciudad con una información más matizada que la noticia de Falange: «continúa el brillante avance japonés, cuyas tropas se encuentran, no en el interior de Nankin como se ha querido decir, pero sí en los suburbios». ${ }^{36}$

Ciertamente, y en la línea de la inminente victoria, el día 10 se plasmaba en la prensa la simultaneidad del flanqueo de las maniobras militares, así como la euforia en Japón: «Las calles de Tokio están hirviendo de júbilo». ${ }^{37}$ En este caso, $\mathrm{y}$ al igual que las ausencias anteriormente aludidas de ciertos eventos, no se

\footnotetext{
30 «El gobierno de los Estados Unidos envió una nueva nota de protesta al Japón» (19-12-1937). Diario Amanecer, p.1.

31 «En Extremo Oriente hubo ayer gran actividad de la aviación japonesa» (24-11-1937). Diario Falange, p. 4.

32 «Los japoneses, a la vista de Nankin» (06-12-1937). Diario Falange, p. 5.

33 Íd.

34 «Japón ha plantado sus banderas en Nankin» (08-12-1937). Diario Falange, p5.

35 «Los japoneses han entrado en los suburdios [suburbios] de Nankin» (08-12-1937). Diario Acción, p.8.

36 Íd.

37 «Tokio, jubiloso, está esperando la caída de Nankín» (10-12-1937). Diario Acción, pp.1 y 5.
} 
encuentran ejemplares que ratifiquen la entrada definitiva de las tropas japonesas en la capital china. Por su parte, uno de los supuestos que se tenía casi por seguro por parte de los mandatarios nipones era que la campaña en China iba a ser breve, más aún con la posesión de los territorios más ricos y estratégicos del país para finales de 1937. Ello quedó también expuesto, bajo el confiado titular de «Toca a su fin el conflicto chino-japonés», cuando «las aseveraciones de los peritos militares ingleses y norteamericanos se ha comprobado que son falsas, puesto que el conflicto que se ha iniciado hace pocos meses ya toca a su fin». ${ }^{38}$ Como consecuencia de la batalla, se dieron a conocer las cifras de muertos y heridos de «ochocientos»y «cuatro mil» respectivamente por parte del bando japonés mientras que los chinos acumularon un total de «ochenta y cuatro mil muertos». ${ }^{39}$ Unas cifras poco exactas dado que los informes nipones tendían a disminuir e inflar los números en cuanto a bajas propias y enemigas respectivamente. Una cantidad aproximada más acertada sería la de 1.953 muertos y 4.994 heridos japoneses y entre 10.000 y 20.000 muertos chinos, aunque estas cifras son siempre objeto de debate entre autores al igual que la ocasionada en la «Masacre de Nankín» la cual está igualmente ausente en la prensa (YАмАмОто, 2000: 87-88).

En efecto, la única descripción de violencia reflejada en este medio de comunicación se hace en lo concerniente al combate militar de Nankín sin demasiados detalles: «la batalla trabada en las calles de la ex-capital china, era de gran intensidad (...) La toma de Nankín ha sido furiosa y violenta y particularmente intensa la actuación de la artillería y de la aviación». ${ }^{40}$ Incluso, días después de la toma de la capital china, se recoge una noticia favorable a la actuación japonesa en el conflicto. Al igual que ocurre con diversos ejemplares, las consignas propagandísticas se imponen a la realidad sobre la que se asientan y es que, ante la fatídica situación de China en alusión a la fractura interna entre nacionalistas y comunistas, se enfatiza que «El agregado militar japonés en esta capital [Peiping según se resalta en la información previa] ha declarado ante los representantes de la prensa extranjera, que el Japón, de acuerdo con su espíritu tradicionalmente caballeroso no intentará aprovecharse de la mala situación en China. El Japón espera - dijo el agregado militar - que China pueda sacudirse del grave peligro que le amenaza por parte del comunismo». ${ }^{41}$ Finalizado el primer año de campaña, a principios de enero de 1938 las dinámicas propagandísticas prosiguieron con su habitual dinámica en el seguimiento de los eventos de la toma de Nankín:

La maravillosa máquina de guerra, que es el ejército nipón está asombrando al mundo con la serie de victorias fulminantes, que han de culminar con la conquista y sujeción de ese gigante debilitado que es China (...) La «democracia», del mundo occidental emplea un truco ya gastado, para desacreditar al Imperio del Sol naciente. El Japón, dicen, es una nación imperialista, que para satisfacer desmesurados apetitos de grandeza ha declarado la guerra a China, desmembrada y pacífica (...)

38 «Toca a su fin el conflicto chino-japonés» (16-12-1937). Diario Acción, p.1.

39 «La guerra chino-japonesa» (30-12-1937). Diario Falange, p.5.

40 «A las tres de la tarde de ayer los japoneses entraron en Nankín» (11-12-1937). Diario Falange, p. 8. 41 «La revolución comunista en el noroeste de China» (17-12-1937). Diario Falange, p. 3. 
Nosotros comprendemos bien los afanes del pueblo nipón, sobrio y disciplinado, y entre la maraña de extraños nombres que nos llegan de la lejanía, vemos cómo va perfilándose nítidamente su triunfo, con la iniciación de una era de influencia japonesa en China; influencia pacificadora y benéfica, no amenazada por el fantasma soviético, definitivamente alejado y sin fuerza. Una obra magnífica que el mundo no comprende. Afortunadamente el Japón es un pueblo vigilante y consciente de su misión. Por eso acaba de conquistar Nankin. ${ }^{42}$

De la misma forma, a finales de este mismo mes se recogieron, favorablemente, las intenciones de los mandatarios nipones sobre el conflicto que conectan con la imagen expuesta por parte de la prensa isleña unas semanas antes. Así, «Hirota subrayó igualmente que Japón no tiene ambiciones territoriales en China y que tampoco anhela separar el Norte de China del resto de la nación, Luego ha expresado que todo lo que desea Japón es la unión chino-japonesa a fin de posibilitar mediante la colaboración chino-japonesa el bienestar y progreso de ambos pueblos». ${ }^{43}$ Igualmente, en la misma noticia se mostraron los futuros planes nipones en China dado que «las fuerzas japonesas, después de la ocupación de la región sur del río Yangtsé preparan otras acciones militares», ${ }^{44}$ aunque no se concreta cuáles. Habría que esperar a un ejemplar días después para conocer que estas acciones consistirían en la toma de la conexión ferroviaria Tianjin-Pukou, así como el aumento de efectivos para lo que parecía ser una prolongación de los enfrentamientos. Además, se resaltaba el inicio de las prácticas guerrilleras chinas. ${ }^{45}$ Ciertamente, desde el Cuartel General Imperial japonés, establecido en noviembre de 1937, se consideraba que el incremento de soldados, que a finales de 1937 sumaban un total de 600.000, era una necesidad imperiosa. Pero a este capital humano se le sumó también la necesidad de supeditar todos los sectores productivos de la economía nacional a los objetivos militares, algo que se expuso igualmente en la prensa. ${ }^{46}$

Paralelamente a la campaña contra el Kuomintang, los eventos relacionados con los choques fronterizos entre Japón y la Unión Soviética fueron el segundo fenómeno bélico más remarcable de 1938, conocido este como el incidente de Changkufeng. Antes de que estallara la principal batalla a la sazón de esta dinámica entre el 29 de julio y el 11 de agosto, esto es la batalla del lago Jasan, ya la prensa en mayo remarcaba la preeminencia de estas dos potencias en torno a la región de Manchuria. Concretamente, el ejemplar mostraba una narrativa propagandística que hundía su discurso en la confrontación fronteriza de estos dos países en perspectiva histórica, especialmente a partir de finales del siglo XIX. Una vez más, la admiración por Japón, justificando sus acciones militares entre sutilezas retóricas y evidentes declaraciones, se erigía como la consigna principal del relato donde el país nipón era el único «baluarte anticomunista en Oriente»

42 «Para la comprensión del conflicto chino-japonés» (14-01-1938). Diario Falange, p. 3.

43 «Ante la Cámara japonesa los gobernantes de Tokio dan cuenta al país que todo su interés está concentrado en salvaguardar la futura paz de Extremo Oriente» (22-01-1938). Diario Falange, p. 8. 44 Íd.

45 «La guerra chino-japonesa» (28-01-1938). Diario Falange, p. 5.

46 Íd. 
con la misión casi determinista de detener «la sovietización de China». ${ }^{47}$ En efecto, la razón de ser de las injerencias rusas en las fronteras chinas quedan supeditadas a sus consignas ideológicas remarcando una complacencia, por tanto, en la loable expansión japonesa en esta región que, entre tantos logros, consiguió «la independencia de Manchuria, que tomó el nombre de Manchu-kuo»». ${ }^{48}$

En lo concerniente a la cobertura informativa de este incidente, habría que esperar hasta el 2 de agosto cuando el diario Acción publicó un número donde puso de relieve las perspectivas soviéticas y japonesas sobre el inicio del choque. A saber, desde las fuentes japonesas se manifestó que la ocupación de la zona se debió por una invasión previa de las tropas rusas, mientras que desde Moscú se desmintió tal información arguyendo que habían sido los contingentes nipones los que habían violado la frontera al ocupar Changkufeng. ${ }^{49}$ Dos días más tarde, y con los combates en auge, el mismo diario plasmó la intención de Japón por resolver el conflicto vía diplomática junto con las protestas del Gobierno japonés a Moscú. Asimismo, los únicos datos de la pugna que se ofrecen se relaciona con una ofensiva soviética del día anterior en el que «atacaron cuatro batallones de infantería soviética, protegidos por 30 tanques, 25 cañones y otro material a las posiciones japonesas de Chaotsopri que se encuentra al norte de ChangkuFeng». ${ }^{50}$ Ciertamente, fue en este incidente cuando el Ejército Rojo probaría por vez primera, junto con el escenario de la Guerra Civil española, un uso intensivo de tanques y aviones de combate. Esta intensificación se recoge también un ejemplar de Amanecer, aunque, al igual que su homologo periodístico, no se ofrecen muchos detalles de las maniobras militares. ${ }^{51}$

Sin embargo, lo que no se recogió en la prensa es que tanto la actuación de la aviación como de las divisiones de tanques dejaron mucho que desear principalmente por una falta de preparación y descoordinación además de las dificultades que presentaba el terreno para el despliegue y acción de los tanques. De hecho, la ofensiva rusa del 2 de agosto careció de un total apoyo aéreo (HiLl, 2017: 87-88). Así pues, y encarando la recta final del conflicto, la prensa ponía de manifiesto la intencionalidad japonesa centrada en cesar los combates fronterizos además de continuar con la inexactitud de los datos de combate: «Japón no está dispuesto a mantener con los Soviets conversaciones de carácter discontinuo (...) con la misión de solventar las cuestiones territoriales de la frontera del Mandchukuo [Manchukuo]. La Agencia Domei dice que detrás del frente ruso se ha concentrado numerosos tanques. La línea fronteriza continúa amenazada por la aviación soviética». ${ }^{52}$ Aunque el fin de las hostilidades entre Japón y Rusia finalizaron con un Alto el fuego el 11 de agosto, las tensiones y escaramuzas se siguieron manteniendo, un aspecto que se refleja en los diarios gran canarios, ${ }^{53}$

47 «El conflicto chino-japonés. Rusia y Japón ante China» (12-05-1938). Diario Acción, p. 3 48 Íd.

49 «La pregunta inquietante: ¿Habrá guerra ruso-japonesa?» (02-08-1938). Diario Acción, p. 8.

50 «El pacifismo de Japón y la persistencia de los conflictos ruso-manchukuos» (04-08-1938). Diario Acción, p. 8.

51 «La situación del conflicto nipón-soviético» (10-08-1938). Diario Amanecer, p. 1.

52 «Stalin no se fía ni del mariscal Voroschiloff» (10-08-1938). Diario Falange, p. 5

53 «Rusia viola el convenio de suspensión de hostilidades con Japón» (17-08-1938). Diario Acción, p. 8. 
hasta que estas culminaron de nuevo con el incidente de Nomonhan al año siguiente.

Volviendo de nuevo al desarrollo de la campaña en China, en la cobertura periodística de las maniobras niponas hacia el centro y sur del continente destacaron las capturas de Hankou, Cantón o Wuhan, puntos que previamente habían sido bombardeados. La ciudad de Wuhan, conectada con las ciudades de Hankou y Wuchang, fue uno de los puntos más importantes en la recta final de las conquistas japonesas donde se apostaron un millón de soldados chinos. No obstante, nada se mencionó sobre su captura o sobre los combates entre las fuerzas imperiales y los defensores liderados por Chiang Kai-shek. La única información de relevancia al respecto viene dada por los bombardeos que la aviación japonesa realizó en dichas ciudades. ${ }^{54}$ Asimismo, tampoco se aluden muchos detalles del ataque anfibio japonés en la captura de Cantón más allá de que el desembarco no encontró una gran resistencia..$^{55}$ Otras informaciones que se plasmaron en este escenario fueron los esfuerzos japoneses por «limpiar las regiones ocupadas de los restos de las tropas chinas y de los guerrilleros chinos», ${ }^{56}$ o lo que es lo mismo la aplicación de la política de contrainsurgencia ideada por Okamura, la retirada de las tropas chinas de Wuhan o la certeza casi completa, y con unas claras consignas propagandísticas, de que con la caída de estas últimas ciudades Japón cruzaría definitivamente el umbral de la victoria acompañada de la finalización del conflicto. ${ }^{57}$

Las noticias relevantes que se expusieron a finales de 1938 estuvieron marcadas por una clara narrativa propagandística en torno a eventos de política exterior. En efecto, los aniversarios del Pacto Antikomintern o del reconocimiento oficial de la España franquista por parte de Japón fueron los sucesos más reseñados. Continuando con la lógica de alineamiento ideológico, lo cierto es que la tónica de estos artículos no difirió en exceso con respecto a los que se mostraron primeramente en este apartado en torno a los eventos diplomáticos. En este sentido, el único valor que reside en la información dada viene por la consigna complaciente que se dejó entrever con respecto a Japón. Una vez más el sentimiento anticomunista se erigió como eje vertebrador de los discursos planteados: «Combatiendo el peligro comunista Japón ha dado el primer paso para realizar su gran ideal que consiste en crear en Extremo Oriente un orden nuevo». ${ }^{58}$ Por su parte, los elogios del reconocimiento a la España de Franco estuvieron imbuidos casi por una mística espiritual, donde Japón y España, contra todo pronóstico, estaban destinados al entendimiento gracias a su hermandad

\footnotetext{
54 «100 aviones japoneses bombardearon ayer trece posiciones chinas de la provincia de Wuhan, sobre las que arrojaron más de dos mil bombas» (12-08-1938). Diario Falange, p. 2. Como se mencionó anteriormente, la prensa solía cometer errores de transcripción de nombres además de ofrecer una información inexacta de los datos que en ella se recogían. En este caso, el error viene dado por calificar a Wuhan como provincia cuando esta era una de las ciudades principales de la provincia de Hubei.

55 «Japón opera a fondo en el sur de China» (13-10-1938). Diario Falange, p. 5.

56 «Rasgos de la próxima campaña japonesa en China» (28-10-1938). Diario Falange, p. 5.

57 «Rusia morirá por asfixia, cerrada por Oriente y Occidente» (26-10-1938). Diario Acción, p. 1. 58 «Hoy, segundo aniversario del pacto anti-Komintern» (25-11-1938). Diario Falange, p. 1.
} 
anticomunista. ${ }^{59}$

Finalmente, el año se cerraría con las intenciones por parte del país nipón de establecer una paz en China. Unas intenciones que se dejaron sentir en la prensa y que fueron adornadas por la loable predisposición japonesa en proponer a China unas condiciones justas. Ciertamente eran justas, a la par que beneficiosas, para el propio Japón, dado que estas consistieron en «el reconocimiento del Manchukuo, la adhesión al Pacto Antikomintern y la libertad de residencia y comercio para los japoneses». ${ }^{60}$ En el ejemplar del día siguiente se resaltó el rechazo del Gobierno chino para negociar una paz enfatizando su predisposición de dejarse embaucar por las presiones soviéticas. ${ }^{61}$ Lo cierto es que la guerra en China estaba convirtiéndose en una auténtica sangría para Japón en muchos aspectos. El volcamiento de todos los recursos del país a la campaña o la militarización de la vida de la sociedad nipona, con un exponencial aumento del reclutamiento o los paupérrimos productos alimenticios que los civiles optaban por medio del racionamiento, son un claro ejemplo de la fatiga que suponía alargar la guerra. La figura del primer ministro japonés, Konoe Fumimaro, fue esencial para el deterioro de esta situación. Siguiendo las premisas de HоттA (2015: 66-67), la política exterior ejercida por Konoe se caracterizó por ser ambigua para con sus intenciones. El primer ministro reconoció el compromiso que suponía mantener una prolongada campaña militar, pero sus acciones derivaron en apoyar más a la facción dura de los militares japoneses, de entre los cuales se encontraban miembros del fallido golpe de estado de 1936, a la par que mantenía una imagen propagandística favorable y exitosa sobre las acciones militares hacia la población japonesa. En su figura política, tal y como sostiene Hotta, se conjugaron el autoengaño y la ineptitud ocasionando así un agravamiento irreparable del conflicto con China.

\section{CONCLUSIONES}

Los enfrentamientos bélicos de las primeras décadas del siglo xx supusieron, entre otros elementos, un uso intensivo de los medios de comunicación por parte de los beligerantes cuyo principal objetivo reside en su carácter más propagandístico. En este sentido, es este carácter propagandístico el que se impone en numerosas ocasiones a la veracidad factual cuyo elemento más informativo se plasma según el prisma pertinente. En este caso, tal como se ha retratado, las relaciones hispanojaponesas de la década de los treinta y los cuarenta estuvieron auspiciadas más por el halo propagandístico y simbólico que por la concreción de una colaboración más tangible salvo en su aspecto más diplomático.

La simultaneidad de guerras en China y en España constituye uno de los momentos álgidos en la idealización de la imagen japonesa a la sazón de sus

59 «I aniversario del reconocimiento del Gobierno de España por el Japón» (01-12-1938). Diario Falange, p. 8

60 «Japón ofrece a China unas condiciones dignas de paz» (23-12-1938). Diario Falange, p. 2

61 «China, al repudiar las generosas proposiciones japonesas deja entrever sus concomitancias con la Rusia soviética» (24-12-1938). Diario Falange, p. 1. 
atributos anticomunistas y nación moderna susceptible de ser imitada. Todo ello quedó bien recogido en la prensa canaria durante los primeros meses de la agresión japonesa a China en 1937 cuando el seguimiento de los eventos bélicos entró en simbiosis con la forja de esta imagen. No obstante, la cobertura de los sucesos del conflicto se caracterizó por ser irregular, explicada en parte por las limitaciones propias de las agencias de prensa españolas que se servían de informaciones dadas por terceros. Una irregularidad palpable no solo en la concreción y matización de la información dada, sino también en la falta de un seguimiento diario o en la ausencia de eventos trascendentes de la segunda guerra sino-japonesa como el incidente del puente de Marco Polo, en este caso tratado muy superficialmente, el fallido ataque chino al crucero Izumo o la masacre indiscriminada que se sucedió en Nankín durante las primeras semanas de su ocupación por parte del Ejército imperial. Esta dinámica no era exclusiva para con las noticias provenientes de Asia, sino que se extendió también al resto de informaciones que se ofrecían como las concernientes a la Segunda Guerra Mundial. Más que informar, la prensa se erigió para proyectar una serie de consignas y generar así una opinión pública favorable respecto al régimen de Franco. En suma, con este trabajo hemos querido poner de relieve la faceta propagandística e informativa de la prensa canaria acerca de la actuación bélica japonesa en los inicios de su agresión a China, así como su uso como mediador favorable en las relaciones hispano-japonesas. Esta última característica puede ser contrastada también con los estudios que se han venido dando desde un ámbito más estatal e inserto en las relaciones más puramente diplomáticas. Por ende, este estudio nos permite ratificar la continuación de un acercamiento ideológico y de política exterior del gobierno franquista con respecto a Japón en los primeros momentos del conflicto en Asia.

\section{HEMEROGRAFÍA}

Diario Acción (de julio de 1937 a octubre de 1938).

Diario Amanecer (de diciembre de 1937 a agosto de 1938).

Diario Falange (de julio de 1937 a diciembre de 1938).

\section{REFERENCIAS}

Aróstegui Sánchez, J. (2001): La investigación histórica: teoría y método, Editorial Crítica, Barcelona.

BENESCH, O. (2014): Inventing the Way of the Samurai. Nationalism, Internationalism, and Bushidō in Modern Japan, Oxford University Press, New York.

Bolitho, H. (1984): «The Myth of the Samurai», en A. Rix y R. Mouer (eds.) Japan's Impact on the World, , Japanese Studies Association of Australia, Nathan: 2-8.

Centeno Martín, M.P. (2019): «Comunicación visual de conflictos: imágenes de la Masacre de Nankín», en A.I. Arévalo Salinas, G. Vilar Sastre, T. Al NajJar TrujILlo (eds.), Comunicación, paz y conflictos, Dykinson, Madrid: 103-113. 
Centeno Martín, M.P. (2020): «Reeditando la guerra en Asia. Noticiarios japoneses en España (1931-1945)», L'Atlante Revista de estudios cinematográficos 1: 101119.

Desvois, J.-M. (1999): «Manuel Tuñón de Lara y la historia de la prensa», en J.L. DE La Granja, A. Reig Tapia y R. Miralles (eds.), Tuñón de Lara y la historiografía española, Siglo xxI, Madrid: 69-76.

Díaz Benítez, J.J. (2004): «La Segunda Guerra Mundial a través de la prensa canaria», XV Coloquio de Historia Canario-Americana, Casa de Colón, Las Palmas de Gran Canaria: 1047-1061.

Dilworth, D. y TAIRA, S. (trad.) (1969): «The Logic of the Species as Dialectics», Monumenta Nipponica, 24: 273-88.

Dolores SÁINZ, María (1996): «Nuevas fuentes historiográficas», Historia y comunicación social 1: 131-143.

Dower, John W. (1986): War without mercy: race and power in the pacific war, Pantheon Books, New York.

DreA, E.J. y VAN DE VeN, H. (2011): «An Overview of Major Military Campaigns during the Sino-Japanese War, 1937-1945», en M. Peattie, E. Drea y H. VAN DE VEN (eds.) The Battle for China. Essays on the Military History of the Sino-Japanese War of 1937-1945, Stanford University Press, Stanford: 27-48.

GARCÍA CABrera, M. (2018): «De la neutralidad a la no beligerancia española en la II Guerra Mundial: análisis a través de la prensa canaria», Anuario de Estudios Atlánticos 64: 1-18.

GeNTILE, E. (2004): Il fascismo in tre capitoli, Editori Laterza, Bari.

Giménez Caballero, E. (1979): Memorias de un dictador, Editorial Planeta, Barcelona.

GimÉnEZ MARTínez, M.A. (2015): «El corpus ideológico del franquismo: principios originarios y elementos de renovación», Estudios Internacionales 180: 11-45.

Giner, S. y Sevilla Guzmán, E. (1975): «Absolutismo despótico y dominación de clase. El caso de España», Cuadernos de Ruedo ibérico 43-45: 83-104.

GonzÁlez Calleja, E. (2012): «La prensa carlista y falangista durante la Segunda República y la Guerra Civil (1931-1937)», El argonauta español 9: 1-44.

Hernández Ramos, P. (2017): «Consideración teórica sobre la prensa como fuente historiográfica», Historia y comunicación social 22: 465-477.

Hill, A. (2017): The Red Army and the Second World War, Reino Unido, Cambridge University Press, New York.

HotтA, E. (2007): Pan-Asianism and Japan's War 1931-1945, Palgrave Macmillan, Nueva York.

HotтA, E. (2015): Japón 1941. El camino a la infamia: Pearl Harbor, Galaxia Gutenberg, Barcelona.

LAI, B. (2017): Shanghai and Nanjing 1937: Massacre on the Yangtze, Osprey Publishing, London.

López-VERA, J. (2016): Historia de los Samuráis, Satori Ediciones, Gijón.

MitTER, R. (2013): Forgotten Ally: China's World War II, 1937-1945, Houghton Mifflin Harcourt, Boston.

Moya Martínez, M.(2019a): La imagen de Japón en España. Prensa, propaganda y cultura (1890-1945), Tesis doctoral, Universidad de Córdoba, UCOPress, 
Córdoba.

Moya Martínez, M. (2019b): «La invasión japonesa de Manchuria vista por la prensa española (1931-1934)», Mirai. Estudios Japoneses 3: 111-125.

Moreno CANTANO, A.C. (2008): Los servicios de prensa extranjera en el primer franquismo (1936-1945), Tesis doctoral, Universidad de Alcalá, Alcalá de Henares.

PAYNe, S.G. (1984): Falange. Historia del fascismo español, SARPE, Madrid.

PIKE, D.W. (2008): Franco and the Axis Stigma, Palgrave Macmillan, New York.

Pineda Cachero, A. (2004): «Más allá de la historia: aproximación a los elementos teóricos de la propaganda de guerra», en A. PENA (ed.), Comunicación y guerra en la historia, Tórculo, Santiago de Compostela: 807-823.

Pizarroso Quintero, A. (1990): Historia de la propaganda. Notas para un estudio de la propaganda política y de guerra, Editorial Eudema, Madrid.

Pizarroso Quintero, A. (1999): «La historia de la propaganda: una aproximación metodológica», Historia y comunicación social 4: 145-171.

Pizarroso Quintero, A. (2005): «La Guerra Civil española, un hito en la historia de la propaganda», El argonauta español 2: 1-18.

Preston, P. (1994): Franco, "Caudillo de España», Grijalbo, Barcelona.

Pulpillo Leiva, C. (2014): «La configuración de la propaganda en la España nacional (1936-1941)», La Albolafia: Revista de Humanidades y Cultura 1: 115136.

Rodao García, F. (1993): Relaciones Hispano-japonesas, 1937-1945, Tesis doctoral, Universidad Complutense de Madrid, Madrid.

Rodao García, F. (1995): «Difícil y sin apoyos políticos. La Representación por España de los intereses japoneses durante la Guerra del Pacífico», Espacio, Tiempo y Forma, Serie V, $H^{\mathrm{a}}$ Contemporánea 8: 179-194.

RoDAO GARCíA, F.(1998): «Japón y la propaganda totalitaria en España, 1937-1945», Revista española del Pacífico 8: 435-454.

Rodao García, F. (2004): La imagen de España en Japón, Real Instituto Elcano, Madrid.

Rodao García, F. (2013): Franco y el imperio japonés. Imágenes y propaganda en tiempos de guerra, Plaza \& Janes, Barcelona.

SATŌ, S. (1994): War, Nationalism and Peasants. Java under the Japanese occupation 1942-1945, Sharpe, Nueva York.

Sevillano Calero, F. (1998): Propaganda y medios de comunicación en el franquismo, Universidad de Alicante, Alicante.

Sevillano Calero, F. (1999): «Cultura, propaganda y opinión en el primer franquismo», Ayer 1: 147-166.

Sevillano Calero, F. (2000): «Notas para el estudio de la opinión en España durante el franquismo», REIS: Revista Española de Investigaciones Sociológicas 90: 229-244.

Sevillano Calero, F. (2014): «La propaganda y la construcción de la cultura de guerra en España durante la Guerra civil», Studia Historica. $H^{a}$ contemporánea 32: 225-237.

Yамамото, M. (2000): Nanking: Anatomy of an Atrocity, Westport, Connecticut, Praeger. 